Volume 2, Nomor 1, Juni 2020

http://jurnal.radenfatah.ac.id/index.php/studiamanageria

\title{
Manajemen Kesiswaan di SDIT (Sekolah Dasar Islam Terpadu) Harapan Mulia Palembang
}

\author{
Yuri Dullah1, Munir ${ }^{2}$ \\ ${ }^{1}$ SDIT Harapan Mulia, Palembang, Indonesia \\ ${ }^{2}$ Fakultas Tarbiyah dan Keguruan UIN Raden Fatah, Palembang, Indonesia \\ yuri_dullah@yahoo.com
}

\begin{abstract}
The purpose of this article is to answer the formulation problem which includes planning, organizing, implementing and controlling. This research used a descriptive approach that explains the characteristics of existing problems. The subjects of this study consisted of the principal, vice principal of curriculum, vice principal of student, head of administration staff and school's operator. Data collection techniques used are guidelines for observation, interview, and documentation. Data analysis used the Miles and Huberman model techniques, namely 1) Data reduction, 2) Data Presentation, and 3) Drawing Conclusions or Data Verification. The results of this study are as follows: 1) Planning, starting from analyzing the needs of students by considering the number of classes and teachers available, conducting student's activities, selecting students, the school orientation period and recording of new student data. 2) Organizing, including the division of students who are divided based on low, medium, and high competencies. Classroom management is carried out by the homeroom teacher which includes classroom management, student attendance, class set up, making a picket list, lesson schedule, arranging student seating, making class plans, and filling out report cards. 3) Implementation, starting from student's discipline, services in school library, canteen, school health treatment, transportation, intracurricular and extracurricular activities. 4) Supervision, consist of some activities to assess the student learning process, graduation and alumni seach.
\end{abstract}

Keywords: student management

Abstrak. Tujuan dari artikel ini adalah untuk menjawab rumusan masalah yang meliputi perencanaan, pengorganisasian, pelaksanaan, dan pengawasan. Penelitian ini dilakukan di SDIT Harapan Mulia Palembang dengan subjek penelitian yang terdiri dari kepala sekolah, waka kurikulum, waka kesiswaan, kepala TU dan operator sekolah. Teknik pengumpulan data yang digunakan adalah pedoman observasi, wawancara, dan dokumentasi. Analisa data menggunakan teknik model Miles dan Huberman, yaitu 1) Reduksi data, 2) Penyajian Data, dan 3) Penarikan Kesimpulan atau Verifikasi Data. Hasil penelitian ini adalah sebagai berikut: 1) Perencanaan, dimulai dari menganalisis kebutuhan siswa dengan mempertimbangkan jumlah kelas dan guru yang tersedia, melakukan penerimaan siswa baru, seleksi siswa baru, masa orientasi sekolah, hingga pencatatan data siswa baru. 2) Pengorganisasian, meliputi pembagian siswa yang dibagi berdasarkan kemampuan rendah, sedang, dan tinggi. Pengelolaan kelas dilakukan oleh wali kelas yang meliputi penataan ruang kelas, absensi siswa, penyusunan perangkat kelas, pembuatan daftar piket, jadwal pelajaran, pengaturan tempat duduk siswa, pembuatan denah kelas, hingga pengisian raport. 3) Pelaksanaan, meliputi bimbingan pendisiplinan siswa, layanan kegiatan intrakurikuler, dan ekstrakurikuler. 4) Pengawasan, meliputi kegiatan menilai proses dan hasil dari pelaksanaan kegiatan yang dilakukan agar sesuai dengan perencanaan yang telah di buat.

Kata Kunci: manajemen kesiswaan

\section{PENDAHULUAN}

Pendidikan seharusnya menjadi wadah untuk mengembangkan segala potensi yang ada pada diri setiap manusia. Tak terkecuali pendidikan Islam. 
Pendidikan Islam merupakan penataan individual dan sosial yang dapat menyebabkan taat pada Islam dan menerapkannya secara sempurna di dalam kehidupan individu dan masyarakat. Selain itu, pendidikan berupaya untuk megembangkan segala potensi kemanusiaan itu dalam koridor ukhrowi tanpa melupakan kepentingan duniawi (An Nahlawi, 1995: 38). Dengan demikian, potensi yang dikembangkan itu dapat membentuk manusia yang mampu bermanfaat baik di dunia maupun akhirat.

Kebutuhan peserta dalam mengembangkan dirinya tentu saja beragam dalam hal pemprioritasan, seperti di satu sisi para siswa ingin sukses dalam hal prestasi akademik dan non akademiknya, namun disisi lain dia juga ingin sukses dalam hal sosialisasi dengan teman sebayanya. Bahkan ada juga siswa yang ingin sukses dalam segala hal. Pilihan-pilihan yang tepat atas keberagaman keinginan tersebut tidak jarang menimbulkan masalah bagi para siswa. Pengembangan potensi intelektual mengarahkan siswa pada pengembangan ilmu pengetahuan dan teknologi yang akan menghantarkan pada kehidupan dunia yang serba canggih ini. Sementara pengembangan potensi spiritual mengarahkan siswa pada kemampuan memiliki spiritual keagamaan, pengendalian diri dan akhlak mulia (Sari, 2014: 2). Oleh karena itu, pendidikan Islam memang diperlukan oleh setiap muslim dalam rangka mewujudkan pengembangan potensi dirinya.

Tidak semua siswa mempunyai kemampuan akademik yang baik. Namun diantara mereka ada yang mempunyai kemampuan non akademik yang baik. Dari sinilah disimpulkan bahwa setiap potensi yang dimiliki oleh siswa harus dikembangkan secara seimbang dan terpadu.

Manajemen adalah suatu proses yang dilakukan agar suatu usaha dapat berjalan dengan baik, memerlukan perencanaan, pemikiran, pengarahan, dan pengaturan serta mempergunakan atau mengikutsertakan semua potensi yang ada, baik personal maupun material secara efektif dan efesien (Imron, 2012). Manajemen diperlukan untuk mampu mengatur suatu usaha agar tujuan yang diharapkan dapat tercapai.

Manajemen kesiswaaan berupaya mengisi kebutuhan layanan yang baik bagi siswa, mulai dari siswa tersebut mendaftarkan diri sekolah sampai siswa tersebut menyelesaikan studinya. Layanan tersebut bersifat kontinu terhadap seluruh siswa agar pembelajaran dapat berlangsung secara efektif dan efesien. Manajemen kesiswaan merupakan proses pengurusan segala hal yang berkaitan dengan siswa, pembinaan sekolah mulai dari penerimaaan siswa, pembinaan siswa berada di sekolah, sampai dengan siswa menamatkan pendidikannya mulai penciptaan suasana yang kondusif 
terhadap berlangsungnya proses belajar mengajar yang efektif (Mantja, 2007: 35). Jadi, pelayanan terhadap siswa secara total merupakan bagian dari manajemen secara umum untuk menghasilkan tujuan yang diharapkan.

Hal inilah yang akan penulis teliti di salah satu sekolah Islam terpadu di Kota Palembang. Penulis akan meneliti mengenai manajemen kesiswaan di SDIT (Sekolah Dasar Islam Terpadu) Harapan Mulia Palembang. Sekolah ini beralamat di jalan Dr. Wahidin No.3 Kecamatan Bukit Kecil di Palembang. Sekolah ini merupakan sekolah yang memiliki akreditasi "A" (Amat Baik). Sekolah ini berusaha untuk selalu meningkatkan mutu pendidikannya. Peningkatan mutu pendidikan ini dibuktikan dengan melakukan pembinaan terhadap siswa sehingga para siswa dapat mencapai prestasi akademik dan non akademik baik di tingkat provinsi maupun nasional. Hal ini lah yang terus di kembangkan dan tingkatkan oleh pihak sekolah dalam rangka mewujudkan visi lembaga itu sendiri yaitu menjadikan lembaga yang berprestasi tinggi dalam pengembangan kecerdasan nalar yang berbasis pengembangan kejernihan dan naluri siswa. Perwujudan visi-misi tersebut juga didukung oleh fasilitas yang memadai. Selain itu pula, sekolah ini memiliki program pembinaan siswa melalui 3 kegiatan, yaitu kegiatan intrakurikuler, ekstrakurikuler, dan ko-kurikuler. SDIT Harapan Mulia sesuai dengan visi dan misi nya mampu mengelola manajemen kesiswaan dengan baik sehingga mampu mengembangkan kecerdasan, bakat dan minat dalam rangka mewujudkan prestasi siswa dalam bidang akademik dan non akademik. Dari paparan di atas, penulis tertarik meneliti tentang perencanaan, pengorganisasian, pelaksanaan hingga tahap pengawasan manajemen kesiswaan di SDIT Harapan Mulia Palembang. Oleh karena itu, penulis memberikan judul penelitian penulis dengan judul Manajemen Kesiswaan di SDIT (Sekolah Dasar Islam Terpadu) Harapan Mulia Palembang.

\section{KAJIAN LITERATUR}

Menurut Terry (1974:4), management is a district proses consisting of planning, organizing, actuating and controlling performed to determine and accomplish stated objectives by the use of human being and other resources. Manajemen adalah proses tertentu yang terdiri dari perencanaan, perorganisasian, pergerakan dan pengawasan yang dilakukan untuk menentukan dan mencapai tujuan yang ditetapkan dengan menggunakan sumber daya personal maupun material, manusia, maupun benda dalam rangka mencapai tujuan yang diinginkan (Purwanto, 1995: 7). Jadi, 
manajemen merupakan proses untuk mencapai sesuatu yang terdiri dari perencanaan, pengorganisasian, pelaksanaan, dan pengawasan.

Fungsi-fungsi manajemen menurut George R. Terry terdiri dari 4 (Empat) fungsi manajemen POAC (Planning, Organizing, Actuating dan Controlling) (Manullang, 2008: 7).

Manajemen Kesiswaan merupakan pengaturan terhadap kegiatan yang berkaitan dengan siswa, dari masuk sampai keluarnya siswa tersebut dari sekolah. Manajemen kesiswaan tidak hanya berhubungan dengan data sisiwa, melainkan adanya aspek lain yang dapat membantu mengembangkan keterampilan siswa. Manajemen kesiswaan bertujuan untuk mengatur berbagai kegiatan dalam kesiswaan agar kegiatan tersebut dapat berjalan lancar, tertib, dan teratur serta mencapai tujuan pendidikan (Mulyasa, 2009: 45).

Manajemen Kesiswaan merupakan proses pengurusan segala hal yang berkaitan dengan siswa, pembinaan sekolah mulai dari penerimaaan siswa, pembinaan siswa berada di sekolah, sampai dengan siswa menamatkan pendidikannya mulai penciptaan suasana yang kondusif terhadap berlangsungnya proses belajar mengajar yang efektif (Mantja, 2007. 35).

Menurut Aliyyah dalam jurnalnya manajemen kesiswaan pada sekolah dasar, manajemen merupakan suatu cara pengaturan peserta didik, mulai dari input, proses, output, dan menjadi outcome dari satuan pendidikan (Aliyyah, 2019:31). Jadi, manajemen kesiswaan merupakan proses pengurusan seluruh kegiatan kesiswaan untuk menghasilkan proses pembelajaran yang efektif.

Adapun tujuan dari manajemen kesiswaan adalah untuk mengatur kegiatan di bidang kesiswaan agar pembelajaran di sekolah dapat berjalan dengan lancar, tertib, dan teratur, sesuai dengan tujuan pendidikan tersebut (Putra, 2016:1). Selain itu, menurut Fadhilah dalam jurnalnya manajemen kesiswaan di sekolah, manajemen kesiswaan bertujuan untuk menata proses kesiswaan mulai dari perekrutan, mengikuti pelajaran sampai dengan lulus sesuai dengan tujuan intuitional agar dapat berangsung secara efektif dan efisien (Fadhilah, 2017:109). Jadi, tujuan manajemen kesiswaan adalah untuk menata dan mengatur seluruh kegiatan kesiswaan agar pembelajaran dapat berjalan dengan efektif dan efesien.

\section{METODE PENELITIAN}

Penelitian ini dilakukan di SDIT Harapan Mulia yang beralamat di jalan Dr. Wahidin nomor 3 kecamatan bukit kecil di Palembang yang dilakukan pada 
bulan Agustus 2019 hingga September 2019 dengan subjek penelitian yang terdiri dari kepala sekolah, waka kurikulum, waka kesiswaan, kepala TU dan operator sekolah. Penelitian ini menggunakan metode penelitian kualitatif sedangkan pendekatan penelitiannya adalah penelitian deskriptif kualitatif. Data yang diperoleh dari penelitian berupa profil sekolah, foto-foto yang berhubungan dengan kegiatan bagian kesiswaan, dan hasil wawancara yang telah dilakukan oleh peneliti dengan beberapa informan yang berdasarkan dengan fokus penelitian. Teknik pengumpulan data dapat dilakukan dengan interview (wawancara), dan dokumentasi. Data yang diperlukan dalam penelitian ini adalah data yang dapat memberikan informasi tentang manajemen peserta didik di sekolah. Teknik analisis data penelitian kualitatif ini dilakukan secara wawancara. Aktivitas dalam analisis data pada penelitian ini adalah reduksi data, penyajian data, dan simpulan. Pengecekan keabsahan data merupakan pembuktian bahwa apa yang telah dialami oleh peneliti sesuai dengan apa yang sesungguhnya ada, serta membandingkan hasil wawancara dari informan satu dan dari informan lainnya. Untuk mengetahui keabsahan data peneliti menggunakan beberapa teknik, yaitu uji kredibilitas yang dengan memperpanjang masa penelitian wawancara dan dokumentasi di lapangan, meningkatkan ketekunan berarti melakukan pengamatan, triangulasi sumber dan teknik.

\section{HASIL DAN PEMBAHASAN}

\section{A. Perencanaan Manajemen Kesiswaan di SDIT Harapan Mulia}

Perencanaan manajemen kesiswaan dimulai dari analisis kebutuhan siswa yang akan diterima, lalu melakukan penerimaan siswa baru dengan memperhatikan kebijakan penerimaan siswa baru, melakukan seleksi penerimaan siswa baru dengan menetapkan dan menentukan kriteria penerimaan siswa baru, dan membentuk prosedur penerimaan siswa baru yang meliputi kegiatan pembentukan kepanitiaan, pengadaan rapat, pembuatan iklan dan pengumuman, seleksi siswa, penentuan siswa yang diterima, pengumuman siswa yang diterima, dan registrasi ulang siswa yang diterima (Matri, 2008: 165).

Perencanaan manajemen kesiswaan di SDIT Harapan Mulia dimulai dengan melakukan analisis kebutuhan siswa. Agar layanan terhadap siswa dapat berjalan optimal, maka tahapan pertama yang dilakukan oleh SDIT Harapan Mulia dalam merencanakan manajemen kesiswaan adalah menganalisis kebutuhan siswa. Kebutuhan siswa dianalisis dengan 
mempertimbangkan jumlah ruang kelas yang ada dan jumlah guru yang mengajar.

Setelah itu, tahapan selanjutnya adalah penerimaan siswa baru. Kegiatan ini dikoordinir oleh tata usaha. Tahapan penerimaan siswa baru dimulai dari pendaftaran, pengisian formulir, hingga tahap perlengkapan administrasi. Setelah tahapan di atas selesai, maka dilanjutkan tahapan selanjutnya yaitu melakukan seleksi terhadap siswa baru sesuai dengan persyaratan umum yang ditentukan oleh diknas Kota Palembang. Syarat utamanya adalah usia anak saat masuk ke jenjang sekolah dasar khususnya di SDIT Harapan Mulia, adalah minimal berusia 6,5 tahun. Setelah itu, sekolah akan melakukan seleksi psikologi kepada siswa baru untuk melihat kearah mana bakat dan minat dari siswa itu sendiri.

Kemudian, SDIT Harapan Mulia mengadakan masa orientasi siswa (MOS). Kegiatan ini dilakukan selama 1 (Satu) hari saja, Tujuan dari kegiatan ini adalah untuk melakukan pengenalan kepada siswa baru terhadap lingkungan sekolah dan teman baru mereka, agar nantinya tidak ada lagi rasa malu diantara mereka. Selain itu, acara MOS juga diisi dengan banyak permainan sehingga siswa tidak terlalu bosan dan jenuh.

Tahapan terakhir adalah pencatatan data siswa oleh bagian ketatausahaan ke dalam buku khusus yang disebut dengan buku induk siswa. Dalam buku induk siswa itu memuat tentang data lengkap mengenai identitas siswa, identitas orang tua atau wali siswa dan nilai belajar dalam setiap semester. Selain buku induk, SDIT Harapan Mulia juga mengkoordinir pendataan kemajuan belajar siswa. Untuk kemajuan dan keberhasilan kegiatan belajar mengajar secara maksimal, diperlukan buku catatan prestasi belajar murid, yang meliputi buku daftar nilai, buku legger dan raport. Buku daftar nilai digunakan untuk menilai hasil belajar yang di peroleh langsung dari kertas pekerjaan ulangan atau dari hasil ujian lisan. Buku legger digunakan untuk menampung nilai-nilai guru bidang studi dalam periodeperiode tertentu. Sedangkan buku raport, digunakan untuk memuat hasil belajar siswa selama siswa tersebut mengikuti pelajaran.

Dari hasil penelitian, penulis menganalisis bahwa perencanaan yang telah disusun oleh pihak SDIT Harapan Mulia, sebagai mana yang telah penulis paparkan di atas secara umum telah sesuai dengan teori dan sesuai dengan perkembangan dan kebutuhan sekolah melalui kegiatan yang inovatif. Semua kegiatan perencanaan itu dilakukan agar pencapaian tujuan sesuai apa yang diharapkan. 


\section{B. Pengorganisasian Manajemen Kesiswaan di SDIT Harapan Mulia}

Pengorganisasian Manajemen Kesiswaan, yaitu penentuan sumber daya manusia dalam hal ini peserta didik ke dalam pengelompokkan kelas kemudian pemberian tanggung jawab kepada wali kelas untuk membina dan mengorganisir bagaimana proses belajar mengajar dengan baik sehingga tujuan bisa dicapai dengan baik (Siagian, 1989).

Pengelompokan siswa di SDIT Harapan Mulia dilakukan terutama bagi siswa baru dengan tujuan agar program kegiatan belajar bisa berlangsung dengan sebaik-baiknya. Pengelompokkan siswa dilakukan pada setiap awal tahun ajaran baru. Setiap kelas di pegang oleh wali kelas. Setiap wali kelas pada masing-masing kelas, mengelompokkan siswa berdasarkan kemampuan yang dibagi menjadi kemampuan rendah, sedang, dan tinggi. Hasil pembagian ini di dapat dari hasil belajar siswa dan pengamatan wali kelas masing-masing.

Pengelolaan kelas merupakan bagian dari tugas guru. Setiap guru baik wali kelas atau guru bidang studi wajib membuat perangkat pembelajaran. Selain itu, guru juga bertanggung jawab terhadap pengelolaan kelas yang meliputi penataan ruang kelas, absensi siswa, penyusunan perangkat kelas, pembuatan daftar piket, jadwal pelajaran, pengaturan tempat duduk siswa, pembuatan denah kelas, hingga pengisian raport.

Dari hasil penelitian tersebut, maka penulis menganalisis bahwa pengelompokkan siswa dilakukan dengan membagi siswa berdasarkan hasil kemampuan siswa yang dibagi dengan kemampuan rendah, sedang, dan tinggi. Sehingga, pengelompokkan siswa dalam satu kelas terdiri dari siswa yang berkemampuan rendah, sedang, dan tinggi. Untuk pengelolaan kelas dilakukan oleh wali kelas yang meliputi semua pengelolaan yang berkaitan dengan siswa agar pembelajaran dapat berlangsung dengan efektif dan efesien.

\section{Pelaksanaan Manajemen Kesiswaan di SDIT Harapan Mulia}

Senada yang diungkapkan oleh Prihatim, bahwa pelaksanaan manajemen kesiswaan sama halnya dengan pembinaan kesiswaan. Pembinaan kesiswaan berarti pemberian layanan kepada siswa disuatu lembaga pendidikan, baik di dalam maupun di luar jam belajarnya di kelas, dengan tujuan terciptanya kondisi dan membuat siswa sadar akan tugas-tugas belajarnya. Oleh karena itu, pelaksanaan manajemen kesiswan meliputi: Pembinaan disiplin siswa, pembinaan kegiatan intrakurikuler, dan pembinaan bakat dan minat melalui kegiatan ekstrakurikuler (Prihatin, 2011: 93). 
Untuk itu, pelaksanaan manajemen kesiswaan di SDIT Harapan Mulia memuat masalah kesiplinan siswa, kegiatan intrakurikuler, dan kegiatan ekstrakurikuler. Dalam hal pembinaan kedisiplinan siswa, sebagaimana diungkapkan oleh Elizabeth bahwa pembinaan kedisiplinan siswa bertujuan untuk mendorong dukungan bagi terciptanya perilaku yang tidak menyimpang, mendorong siswa melakukan yang baik dan benar, membantu siswa memahami dan menyesuaikan diri dengan tuntutan lingkungannya dan menjauhi melakukan hal-hal yang dilarang oleh sekolah, siswa belajar hidup dengan kebiasaan-kebiasaan yang baik dan bermanfaat baik serta lingkungannya (Elizabeth, 1989: 82). Untuk itulah, SDIT Harapan Mulia membuat peraturan atau tata tertib bagi siswa. Pembuatan tata tertib ini didasarkan atas hasil musyawarah antara kepala sekolah dengan para dewan guru, dan staf tata usaha yang sifatnya tidak tetap, karena tata tertib itu suatu saat bisa berubah tergantung situasi dan kondisi lingkungan sekolah. Dalam tata tertib siswa SDIT Harapan Mulia memuat tentang kewajiban khusus, Hak-hak siswa, perihal pakaian siswa dan berhias, memuat laranganlarangan bagi siswa, sanksi-sanksi, dan memuat absensi. Bagi siswa yang melanggar tata tertib sekolah akan dikenakan sanksi, berdasarkan pelanggaran yang dibuatnya.

Untuk kegiatan intrakurikuler adalah kegiatan utama persekolah yang dilakukan dengan menggunakan alokasi waktu yang telah ditentukan dalam struktur program. Kegiatan ini dilakukan guru SDIT Harapan Mulia dan siswa dalam jam-jam pelajaran setiap hari. Kegiatan intrakurikuler ini dilakukan untuk mencapai tujuan minimal setiap mata pelajaran/ bidang studi yang tergolong inti maupun khusus. Intrakurikuler juga merupakan kegiatan proses belajar-mengajar di kelas yang merupakan kegiatan utama sekolah. Sekolah diberi kebebasan memilih strategi, metode, dan teknik-teknik pembelajaran dan pengajaran yang efektif, sesuai dengan karakteristik mata pelajaran, siswa, guru, dan kondisi nyata sumber daya yang tersedia di sekolah.

Sedangkan untuk kegiatan ekstrakurikuler, dilaksanakan di SDIT Harapan Mulia juga terdiri dari 2 (dua) kegiatan lainnya, yaitu kegiatan pengembangan diri, dan sanggar. Kegiatan ini adalah kegiatan diluar jam pelajaran biasa (termasuk pada waktu libur) yang dilakukan disekolah ataupun di luar sekolah dengan tujuan memperluas pengetahuan siswa mengenai hubungan antara berbagai mata pelajaran, menyalurkan bakat dan minat serta melengkapi upaya pembinaan manusia seutuhnya. Hal ini senada dengan yang diungkapkan oleh Mulyono, bahwa kegiatan ekstrakurikuler 
$\overline{\text { merupakan kegiatan yang dilakukan di luar kelas dan di luar jam pelajaran }}$ (kurikulum) untuk menumbuh kembangkan potensi sumber daya manusia (SDM) yang dimiliki siswa (siswa) baik berkaitan dengan aplikasi ilmu pengetahuan yang didapatkannya maupun dalam pengertian khusus untuk membimbing siswa dalam mengembangkan potensi dan bakat yang ada dalam dirinya melalui kegiatan-kegiatan yang wajib maupun pilihan (Mulyono, 2008: 98).

Kegiatan pengembangan diri di SDIT Harapan Mulia, terdiri dari kegiatan-kegiatan yang mampu mengembangkan bakat dan minat siswa. Diantaranya adalah olimpiade MTK dan IPA, bidang bahasa Inggris yang meliputi speech dan speeling bee, pengembangan kemampuan agama Islam yang meliputi cerdas cermat PAI, dai cilik, dan adzan, dan pengembangan diri melalui polisi cilik. Sedangkan sanggar, merupakan kegiatan yang mampu membina bakat dan minat siswa, mulai dari sanggar tari, band, karate, sanggar lukis, futsal dan taman pendidikan al-Qur'an (TPA).

Dari hasil penelitian di atas, maka penulis menganalisis bahwa pelaksanaan manajemen SDIT Harapan Mulia berkaitan dengan pembinaan dan pelayana bagi siswa untuk mendidik kepribadian siswa dan membina segala potensi dan bakat yang dimiliki oleh siswa masing-masing melalui kegiatan-kegiatan intrakurikuler dan ekstrakurikuler.

\section{Pengawasan Manajemen Kesiswaan di SDIT Harapan Mulia}

Berdasarkan apa yang dikemukakakan oleh Arikunto, bahwa pengawasan merupakan sebuah proses pengumpulan data untuk menentukan sejauh mana, dalam hal apa, dan bagian mana tujuan pendidikan sudah dicapai. Pengawasan merupakan kegiatan menilai proses dan hasil belajar peserta didik, baik berupa kegiatan kurikuler, non kurikuler, maupun ekstrakurikuler yang bertujuan untuk melihat kemajuan siswa dalam menguasai materi pembelajaran sesuai dengan tujuan yang telah dirumuskan (Arikunto, 2008: $3)$.

Pengawasan manajemen kesiswaan yang dilakukan di SDIT Harapan Mulia dilaksanakan oleh kepala sekolah. Hal tersebut dilakukan karena tanggung jawab penyelenggaraan semua kegiatan pendidikan di sekolah ini berada ditangan kepala sekolah. Jika terdapat penyimpangan itu berarti akibat dari kelalaian pengawasan yang dilakukan oleh pihak sekolah khususnya kepala sekolah. Pengawasan merupakan bagian dari manajemen yang diterapkan di sekolah ini adalah salah satu bentuk refleksi yang nantinya dapat digunakan oleh pihak sekolah dalam merancang perencanaan 
baru mengenai manajemen kesiswaan. Adanya pengawasan manajemen kesiswaan itu berarti akan terbentuk perbaikan dalam pengelolaan sistem manajemen dan perencanaan yang diterapkan oleh pihak sekolah khususnya yang berkaitan dengan manajemen kesiswaan. Hal ini Senada dengan yang diungkapkan oleh Terry bahwasanya dengan adanya kemampuan kepemimpinan pengelolaan manajemen akan menjadi lebih terarah dan mencapai tugas serta tujuan dalam penyelenggaraannya (Terry, 2009: 152). Adanya pengawasan dalam manajemen kesiswaan merupakan hal yang sangat penting bagi sekolah.

Dari hasil penelitian di atas, penulis menganalisis bahwa pengawasan manajemen kesiswaan di SDIT Harapan Mulia dilakukan oleh kepala sekolah selaku manager/ pimpinan sekolah, dalam hal ini berfungsi untuk menilai/mengawasi jalannya kegiatan agar pelaksanaan kegiatan kesiswaan sesuai dengan perencanaan yang telah ditentukan.

\section{KESIMPULAN}

Hasil dari analisis terhadap data-data yang diperoleh dari wawancara, observasi, dan dokumentasi mengenai manajemen kesiswaan di SDIT (Sekolah Dasar Islam Terpadu) Harapan Mulia dapat disimpulkan sebagai berikut:

Pertama, Semua perencanaan yang disebutkan dalam hasil penelitian secara umum telah sesuai dengan prosedur yang ditetapkan oleh pihak SDIT Harapan Mulia. Kepala sekolah selaku manajer pendidikan di sekolah telah melakukan perencanaan manajemen kesiswaan dengan baik. Sekolah ini menyusun perencanaan manajemen kesiswaan sesuai dengan perkembangan dan kebutuhan sekolah melalui kegiatan yang inovatif. Semua kegiatan manajemen kesiswaan dikoordinir dengan baik agar pencapaian tujuan sesuai apa yang diharapkan.

Kedua, pengorganisasian manajemen kesiswaan yang dilaksanakan di SDIT Harapan Mulia terdiri dari kegiatan pembagian kelas dan pengelolaan kelas. Kegiatan pembagian kelas atau pengelompokkan kelas dibagi berdasarkan kemampuan, dimana kemampuan tersebut dibagi menjadi kemampuan rendah, sedang, dan tinggi. Sedangkan pengelolaan kelas meliputi penataan ruang kelas, absensi siswa, penyusunan perangkat kelas, pembuatan daftar piket, jadwal pelajaran, pengaturan tempat duduk siswa, pembuatan denah kelas, hingga pengisian raport.

Ketiga, setelah direncanakan kegiatan manajemen kesiswaan, maka hal selanjutnya yang dilakukan adalah dengan melaksanakannya sesuai yang 
telah direncanakan sebelumnya. Pelaksanaan tersebut dapat dilakukan dengan memberdayakan kegiatan-kegiatan peserta didik seperti melatih dan mengasah keterampilan peserta didik sesuai dengan bakat dan minat peserta didik. Dalam hal ini pihak SDIT Harapan Mulia membuka dan memberikan kesempatan kepada para siswa untuk mengikuti kegiatan-kegiatan ekskul dengan baik, dan melibatkan semua pihak sekolah tersebut untuk membimbing dan memotivasi siswa melalui kegiatan-kegiatan yang telah direncanakan.

Keempat, kegiatan manajemen kesiswaan berupa pengawasan manajemen kesiswaan dilaksanakan oleh pihak sekolah sesuai dengan ketentuan dan kebijakan yang ada. Pengawasan kegiatan manajemen kesiswaan di SDIT Harapan Mulia dilakukan secara langsung oleh kepala sekolah. Hal ini dilakukan karena penanggungjawab atas semua kegiatan yang berlangsung di sekolah ini merupakan bagian dari kepala sekolah.

\section{DAFTAR PUSTAKA}

Aliyyah. (2019). Manajemen Kesiswaan pada Sekolah Dasar. Jurnal Pendidikan Guru Sekolah Dasar. 6, 31.

An-Nahlawi, A. (1995). Pendidikan Islam di Rumah, Sekolah, dan Masyarakat. Jakarta: Gema Insani Pers.

Arikunto, S. (2008). Manajemen Pendidikan. Yogyakarta: aditya Media

Elizabeth, B.H. (1989). Perkembangan anak. Jakarta: Erlangga.

Fadhillah. (2017). Manajemen Kesiswaan di Sekolah. Jurnal Studi Pemikiran, Riset, dan Pengembangan Pendidikan Islam. 5, 109.

Imron, Ali. (2012). Manajemen Peserta Didik Berbasis Sekolah. Jakarta: Bumi Aksara.

Mantja, W. (2007). Profesionalisasi Tenaga Kependidikan. Malang: Elang Emas.

Manullang. (2008). Dasar-dasar manajemen. Yogyakarta: Gadjah Mada Univrsity Press.

Matri, N. (2008). Implementasi Dasar-Dasar Manajemen Sekolah dalam Era Otonomi Daerah. Makasar: Aksara Madani.

Mulyasa. (2009). Manajemen Berbasis Sekolah. Bandung: PT Remaja Rosdakarya.

Mulyono. (2008). Manajemen Administrasi dan Organisasi Pendidikan. Jogjakarta: AR-Ruzz Media Groups.

Prihatin, E. (2011). Manajemen Peserta Didik. Bandung: Afabeta. 
Putra, A. (2016). Layanan Khusus Peserta Didik (Kesiswaan). Journal of Islamic Education Management. 2, 1.

Purwanto, N. (1995). Administrasi dan Supervisi Pendidikan. Bandung: PT. Remaja Rosda Karya.

Sari, R. N. (2014). Manajemen Kesiswaan di MTs Daru A'mal Metro Jurnal. Bojonegoro: FKIP Unila.

Siagian, H. (1989). Administarsi Pendidikan Suatu Pendekatan Sistemik. Semarang: PT Satya Wacana 